\title{
Research
}

\section{Understanding Resilience in a Vulnerable Industry: the Case of Reef Tourism in Australia}

\author{
$\underline{\text { Duan Biggs }}^{1}$
}

\begin{abstract}
Understanding the resilience of vulnerable sectors of social-ecological systems is critical in an era of escalating global change. The coral reef tourism sector is highly vulnerable not only to ecological effects of climate change and other anthropogenic disturbances on reefs, but also to shocks such as economic recession and energy price escalation. Commercial tourism enterprises are key players in reef tourism in Australia and elsewhere. However, the factors that confer resilience to reef-based tourism enterprises, or the reef tourism sector more broadly, in the face of large disturbances have not been investigated to date. This paper empirically examines the perceived resilience of reef tourism enterprises on Australia's Great Barrier Reef to large disturbances or shocks. Binary logistic regression analysis of two measures of enterprise resilience demonstrates the importance of human capital in strengthening enterprise resilience. Lifestyle identity, measured as the extent to which owners and senior managers are active in reef tourism as a lifestyle choice, is positively related to enterprise resilience. Finally, reef tourism enterprises indicate that financial and marketing support are the most important actions that government can take to support enterprises in the face of a large shock.
\end{abstract}

Key Words: coral reefs; disturbance; global change; resilience; shock; tourism; vulnerability

\section{INTRODUCTION}

It has become increasingly important to understand and manage the resilience of vulnerable socioeconomic sectors. Continued climate change, deteriorating ecological conditions, and ongoing loss of global biodiversity have the potential to result in an escalating number of disturbances and shocks to social-ecological systems (Millennium Ecosystem Assessment 2005, IPCC 2007, Balmford et al. 2009, Rockstrom et al. 2009). These ecological disturbances occur against a backdrop of conventional drivers including economic, cultural, political, and institutional pressures (Marshall 2010). In addition, catastrophic events such as the recent BP oil spill in the Gulf of Mexico exemplify the type of large scale disturbance that can result from the use of increasingly sophisticated technology to access declining resources (Thomson 2010). Because of economic market linkages and flows of resources and people, impacts of crisis and shocks may spread rapidly in novel and unexpected ways (Adger et al. 2009). For example, international security concerns following the 2001 attacks on the
United States and the SARS outbreak in Asia in 2003 affected travel globally (Hall et al. 2003). Similarly, the global financial crisis of 2008-2009 emanated from the U.S. housing market but quickly spread to affect availability of credit across most sectors of the global economy (Brunnermeier 2009). Interaction between probiofuel policies of western Europe and the USA, increasing energy prices, and droughts in key food production regions led to food riots and shortages across central America, Africa, and Asia (Beattie 2008). This increased uncertainty about timing of major disturbances, and how these disturbances may spread, is of particular concern to socioeconomic sectors that depend on the flow of people and money from distant parts of the globe such as the global tourism industry.

Although international flows of travelers are quite resilient to disturbances globally, e.g., tourism arrivals decreased only $4.2 \%$ during the global financial crisis of 2009 (UNWTO 2010), individual countries, destinations, and market sectors can be subjected to high levels of volatility in tourist demand in response to socio-political, economic, 
and natural resource crises. For example, from January to April 2009, tourism arrivals to Europe dropped by $10 \%$, and the Middle East by $18 \%$ as a result of the global financial crisis. Similarly, the attacks in September 2001 resulted in sharp declines in outbound travel from the USA (Hall et al. 2003). Countries and destinations highly dependent on U. S. tourists were particularly affected. Because of ongoing global change, there is much uncertainty about which disturbances or crises may occur where, and when and how systemic and global effects of these disturbances may spread (Sheldon and Dwyer 2010). Sectors of the tourism industry that depend on a natural resource base highly vulnerable to global change such as coral reef tourism also face added pressure and uncertainty.

Coral reef tourism plays a growing role in the economies of many tropical maritime countries (Gössling 2003, Access Economics 2007, Andersson 2007), yet the threats to coral reef ecosystems are particularly acute and include coral bleaching, ocean acidification, overfishing, and fertilizer and sediment runoff (Bellwood et al. 2004, Hughes et al. 2003, Hennessy et al. 2007). There is concern over the impact of continued degradation of coral reefs on the future of reef tourism (Andersson 2007, Hennessy et al. 2007). The uncertainties facing reef tourism are, however, not restricted to the threats facing coral reef ecosystems. The reef tourism sector is also affected by sociopolitical and economic disturbances described above such as international security and health concerns, economic recessions and resource price shocks, as well as national and local level issues including the regulatory environment (Hall et al. 2003, Gössling and Hall 2006, Baker and Coulter 2007, Simpson et al. 2008, Adger et al. 2009, Hall 2010). Therefore, there is a need to understand the factors that enable the reef tourism industry to cope with, and make positive adaptations, in the face of increasing global change and associated shocks and disturbances. A resilience-based approach to understanding and managing reef tourism is useful as it considers the ability of a system to maintain its functional characteristics and identity in a coupled social-ecological system in the face of disturbances and ongoing often unpredictable change (Adger 2000, Gunderson and Holling 2002).

Coral reef tourism is therefore a good example of a vulnerable sector through which to understand resilience, yet the resilience of reef tourism to global change-related shocks has not been investigated to date. Indeed, the few studies on resilience in tourism systems provide conceptual perspectives on the value of the resilience concept to understanding tourism (Farrell and Twining-Ward 2004, Cochrane 2010) and qualitative applications of the concept to protected areas and community-based tourism (Strickland-Munro et al. 2010, Ruiz-Ballesteros 2011). The contribution of this paper is to quantitatively explore the components of perceived resilience of coral reef tourism enterprises on Australia's Great Barrier Reef to large shocks and disturbances. A secondary objective of this paper is to elucidate information from reef tourism enterprises on proposed government interventions to strengthen enterprise resilience in the face of large shocks. Enterprise resilience is defined and its components discussed in the remainder of the introduction and methods. The results, discussion, and conclusions follow thereafter.

\section{Defining and measuring enterprise resilience}

Direct measurement of resilience requires determining thresholds that separate alternate stable states in a social-ecological system (Carpenter et al. 2005). In a reef tourism system, at the scale of a small nation or city, society may shift from a stable state with an economy based mainly on reef tourism to a stable state in which the main form of economic activity is casino tourism or mining. Similarly, at the enterprise scale, a shift may occur from a condition of solvency to insolvency, or from a core business of reef tourism to casino tourism. However, it is difficult to detect a threshold without crossing it (Carpenter et al. 2005). Measuring present day or future resilience, in the absence of a historical analysis of a threshold-crossing event, requires the use of resilience surrogates (Carpenter et al. 2005, Cumming et al.2005). Use of surrogates acknowledges that important aspects of resilience may not be directly observable and must be inferred. In this study, a resilient reef tourism enterprise is defined as one that is able to maintain its existing level of employment and income and stay operating in reef tourism in the face of a large disturbance or disturbances. Enterprise resilience was measured using both a composite scale and by a binary measure of whether an enterprise indicated it would stay in the reef tourism sector or not in a shock scenario (Table 1). 
Table 1. List of independent and explanatory variables used in this study. The interviewees from enterprises were either owners or senior managers.

\begin{tabular}{|c|c|}
\hline Variable & Variable description \\
\hline \multicolumn{2}{|l|}{ Independent variables } \\
\hline $\begin{array}{l}\text { Enterprise Resilience composite } \\
\text { scale }\end{array}$ & Composite scale of social resilience (see Table 3) \\
\hline $\begin{array}{l}\text { Enterprise Resilience - exit or } \\
\text { not }\end{array}$ & $\begin{array}{l}\text { Binary variable }(1=\text { exit, } 0=\text { not exit }) \text { of whether an enterprise indicates it will exit the } \\
\text { reef tourism sector or not in the face of a shock scenario that leads to } 50 \% \text { reduction in } \\
\text { tourist revenue to the enterprise for } 12 \text { months }\end{array}$ \\
\hline
\end{tabular}

Explanatory variables

Enterprise size

The size of an enterprise measured by the natural logarithm of the number of equivalent full time employees

Enterprise age

The natural logarithm of the number of years an enterprise has been in operation

Enterprise shock experience

Binary variable ( 1 = past shock, $0=$ no past shock) of whether an enterprise has experienced a slump of $25 \%$ or more in its tourism revenue for 3 months or more (beyond seasonal variation)

Condition of coral reefs

Social capital

5 point Likert scale of an enterprise's perspective of the condition of the coral reefs that are the focus of an enterprise's tourist activities

The average of an enterprise's a) expected extent of support from government, b) family and friends, and c) increased collaboration with other companies in a systemic shock scenario (all measured on 5 point Likert scales)

Access to finance in shock scenario

5 point Likert scale of an enterprise's expected ease of access to finance in a systemic shock scenario

Financial condition in shock scenario

The average of an enterprise's expected level of indebtedness, profit and revenue in a systemic shock scenario of a 50\% reduction in tourist revenue to the enterprise for 12 months (all measured on 5 point Likert scales)

Human capital

5 point Likert scale of the confidence of owners and managers in the ability of the key staff in their enterprise to adapt successfully to future changes

Lifestyle identity

Composite scale of the extent to which the participation of owners and managerial staff in a reef tourism enterprise are driven by lifestyle decisions (Table 2)

\section{Components of enterprise resilience}

Diverse factors can strengthen the resilience of reef tourism enterprises and their capacity to innovate, reorganize, and adapt (Table 1). Access to finance, and healthy revenue and profit levels are integral to business survival and success (Bates 1990, HoltzEakin et al. 1994). A review of the tourism and enterprise survival literature identified the following factors as also important: (1) enterprise age, size, and experience, (2) ecological condition of reefs that enterprises visit with their clients, (3) levels of social and human capital, and (4) lifestyle values of enterprise owners and staff that motivate their participation in the tourism industry. These are discussed in turn.

An enterprise's age is generally positively related to its future survival because enterprises are more likely to close down in the first few years of their 
operation (Dunne and Hughes 1994, Bosma et al. 2004, Hall and Williams 2008). Young enterprises suffer liabilities of newness involving both internal processes, such as coordinating and defining roles and developing trust and loyalty among employees, and external problems like acquiring financial capital and resources (Dunne and Hughes 1994). However, enterprise age and success may not exhibit a linear relationship. Older enterprises may display rigidity, and the lack of capacity to adapt (Fritsch et al. 2006). In addition, the size of an enterprise can be an important determinant of how enterprises respond to crises and change in general. This is because smaller and medium-sized enterprises in tourism are often as focused on maintaining the desired lifestyle of the owners as they are toward profit and growth (Ateljevic and Doorn 2000, Hall and Rusher 2004). Moreover, a lack of enterprise experience in dealing with crises is a contributing factor in 9 out of 10 enterprise failures (Kalleberg and Leicht 1991). Changes in the operational procedures of enterprises usually occur as a result of a novel experience which challenges existing norms and routines (Berkhout et al. 2006).

Experiences of tourists to nature-based attractions are influenced by the perceived quality of the feature of primary interest at a destination (Deng et al. 2002). Tourists are less likely to return to a reef destination after reef degradation or coral bleaching (Westmacott et al. 2000, Graham et al. 2001, Uyarra et al. 2005, Kragt et al. 2009) and they are willing to pay more to experience a reef that is perceived as more pristine (Cesar 2000). The perceived quality of coral reefs to which reef tourism enterprises take their clients is therefore potentially important in an enterprises' ability to be resilient to shocks. Importantly, although tourists to coral reefs are able to detect some levels of biological degradation in reefs, there is variation in the accuracy of their perceptions (Uyarra et al. 2009).

Human and social capital are important for enterprise survival and success. Human capital refers to the skills and human capacity of an enterprise (Bosma et al. 2004). Markets such as reef tourism require high levels of human capital to provide a quality product and a memorable experience to visitors, which is adapted and adjusted according to their needs (Burns 1997, Kaplan 2004, Smith 2005, Hall 2009). Social capital refers to the social bonds and norms of reciprocity and trust that enables groups and society to function (Pretty
2003). Social capital is important in enabling economic growth and development and for enhanced productivity (Uphoff and Wijayaratna 2000). Investment in building social capital is also important in fostering business growth and success and enables enterprise innovation (Bosma et al. 2004, Hall 2009). Furthermore, the capacity of individuals and groups to cope with uncertainty and surprise is strengthened through the bonds and support enabled by higher levels of social capital (Adger 2003, Folke et al. 2005). A broad conception of social capital includes the relationship between enterprises and local, state, and national government bodies. The relationship between enterprises and different levels of government are an important determinant of enterprise ability to adapt and innovate in response to pressures or change (Hall and Williams 2008, Hjalager 2010). Government institutions can foster innovation and support ongoing adaptation by enterprises, but at the same time, challenges to good governance that include power struggles, corruption, overregulation and institutional inertia can stifle attempts by enterprises to adapt and change (Hall 2009).

Small tourism entrepreneurs and suppliers, particularly in nonurban areas, are often strongly driven by noneconomic factors such as lifestyle (Williams et al. 1989, Ateljevic and Doorne 2000, Shaw and Williams 2004). Not infrequently, small tourism entrepreneurs in popular rural locations have been repeat visitors to those locations prior to settling in a chosen locale for lifestyle reasons that include a strong sense of place, and positive identity associated with operating an enterprise in a particular location (Williams et al. 1989, Ateljevic and Doorn 2000). Lifestyle considerations by small tourism entrepreneurs alter the entry and exit characteristics of enterprises operating in such rural tourism sectors beyond pure economics (Ateljevic and Doorne 2000). In addition, lifestyle entrepreneurs can play an instrumental role in fostering innovation and the delivery of new products in a tourism sector. Considerations of lifestyle, sense of place, identity, and associated cultural values thus have bearing on determinants of enterprise resilience in economic sectors such as reef tourism. In this paper, the term lifestyle identity is used to describe the extent to which the involvement of owners and senior managers in reef tourism are driven by considerations of lifestyle, sense of place, and identity, as opposed to purely profit motives. 


\section{METHODS}

\section{Study site}

Australia's Great Barrier Reef (GBR) is the world's premier reef tourism destination (Seven Natural Wonders 2008). Tourists visiting the GBR contributed A $\$ 5.8$ billion to the Australian economy per annum in 2005-2006 and sustained 55,000 jobs (Access Economics 2007). The GBR is located on Australia's tropical north-east coast in the state of Queensland. The reef extends north-south for more than $1200 \mathrm{~km}$ (Johnson and Marshall 2007) and is comprised of 2900 individual reefs and approximately 900 islands. The Great Barrier Reef Marine Park, created in 1975 to conserve the reef ecosystem, is $350,000 \mathrm{~km}^{2}$ in extent. The majority of reefs on the GBR lie over $20 \mathrm{~km}$ offshore and require well-equipped boats to visit. This study therefore focuses on tourism enterprises that take visitors to offshore reefs. These enterprises are central to the continuation of reef tourism as an important socioeconomic sector in the GBR region.

This study collected data in the Cairns and the Whitsundays regions, the two iconic and most important areas for reef tourism on the GBR and in Australia. Since 1994, an average of $88 \%$ of tourists who visit the Great Barrier Reef do so in the Cairns and Whitsunday regions (Fig. 1, GBRMPA 2009). The Cairns region has undergone extensive tourist infrastructure development since the early 1980s. This enabled an increase of tourist numbers from 400,000 in 1986-1987 to 1.3 million in 1996-1997 (Prideaux 2000). The majority of this increase was made up of international visitors, and was facilitated by construction of an international airport, marina, long distance coach facilities, and development of international standard hotels, shopping complexes, and golf courses (Prideaux 2000). Between June 2008 and June 2009, there were 2.2 million overnight visitors to the Cairns region, a $2 \%$ decline from 2007-2008 due to the global financial crisis (Tourism Queensland 2009a). The Whitsundays region consists of 74 islands in the central GBR and is a popular holiday destination. The main localities offering tourist accommodation are the mainland town of Airlie Beach, a popular backpacker's destination, and Hamilton Island. The Whitsundays region experienced a doubling in overnight visitor numbers from 464,000 in 1998 to 848,000 in 2002 (Moscardo et al. 2003, GBRMPA 2009). The Whitsundays region had 625,000 overnight visitors between June 2008 and June 2009. This represented a $15 \%$ decline from 2007-2008, following years of stagnation in numbers from 2002 onward. The drop in 2008-2009 was due to the global financial crisis and exacerbated by a reduction in the number of flights servicing the Whitsundays (Tourism Queensland 2009b).

\section{Interview surveys}

Surveys focused on enterprises whose dominant source of income is taking visitors to reef attractions to dive and snorkel. The author compiled a complete list of reef tourism enterprises that met this criterion in the study area. The Great Barrier Reef Marine Park Authority (GBRMPA), the agency responsible for conservation of the GBR, provided a list of Ecotourism Australia accredited tour operators. Because it is voluntary and therefore not all tourism enterprises have Ecotourism Australia accreditation, the list of accredited operators was expanded through contacting regional tourism agencies in each region, i.e., Tourism Whitsundays and Tourism Tropical North Queensland. The membership list of the Association of Great Barrier Marine Park Tourism Operators was also used. These lists were further augmented through internet searches on Google by using the terms "diving" and "snorkeling" and the names of the main tourist destinations within the study area. Furthermore, travel agents and tour booking offices in the tourism centers of Port Douglas and Cairns, both in the Cairns region, and Airlie Beach, in the Whitsundays region, were asked whether the list of reef tourism enterprises was complete. In total, 42 enterprises from the Cairns region and 34 from the Whitsundays region were identified.

The author personally conducted all surveys through semistructured interviews. A semistructured interview has a fixed list of questions, but respondents are able to provide more detail on any topic if they choose to (Bernard 2002). This enabled the collection of more nuanced and contextual information to support quantitative data collected. In some cases, certain pertinent quotes were recorded verbatim. Interviews varied in length from 25 to 90 minutes because of time availability of interviewees and extent of open-ended discussions during the interview. Open-ended questions were used to gain input on proposed government support measures in a shock scenario and obtain data on enterprise age and history. Enterprise age was 
Fig. 1. Trends in visitors to the Great Barrier Reef and the Cairns and Whitsundays regions from 1994 to 2008. Source: GBRMPA 2009: Visitor data for Cairns to Cooktown Management Area and Whitsundays Planning Region http://www.gbrmpa.gov.au/corp site/key issues/tourism/management/ gbr visitation/numbers.

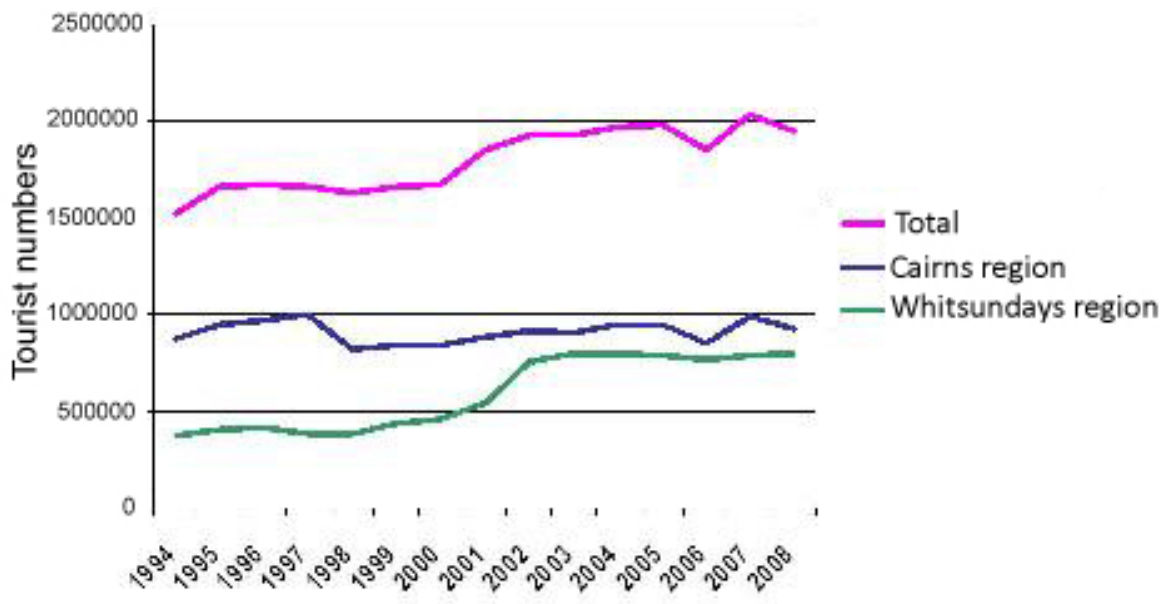

recorded in years, and the natural logarithm of enterprise age was used in the analysis. Similarly, enterprise size was measured by number of employees, and the natural logarithm of enterprise size was used in the analysis. An enterprise's experience of a past shock in this study was measured by whether or not an enterprise had experienced a slump of $25 \%$ or more in its tourism revenue for 3 months or more (Table 1). For all other variables and questions, either binary response options or a 5 point Likert scale were used (Likert 1967; Table 1). The Likert scale response statements were: 1 = strongly disagree (very bad), $2=$ disagree (bad), $3=$ average/indifferent, $4=$ agree $($ good), and $5=$ strongly agree (very good).

The average of three types of social capital were considered in this study (Table 1): first, the social capital that exists between the different levels of government and its subjects; second, the social capital that exists between family members, friends, and within a community; and third, the social capital that exists between actors in the reef tourism sector, which enables them to work together when necessary. Human capital was measured through reported confidence of owners and managers in the ability of the key staff in their enterprise to adapt successfully to future changes (Table 1). Enterprise owner's or manager's perceived access to finance in a systemic shock scenario and the average of the expected level of indebtedness, profit, and revenue in a systemic shock scenario was also measured (Table 1). Lifestyle identity was measured as the extent to which the participation of owners and managerial staff in a reef tourism enterprise is driven by lifestyle decisions (Tables 1 and 2).

Composite scales were developed as measures of enterprise resilience and lifestyle identity (Tables 2 and 3). Composite scales are created by combining two or more single-statement scales into one measure (Bernard 2002). Each single scale captures a component of the concept, and together they produce one measure of a more complex issue. Reliability analysis was used to ensure that only statements that contributed to the internal consistency of the composite scales were included (Zeller and Carmines 1980; Tables 2 and 3). The Cronbach's $\alpha$ score of the composite scales for both social resilience and lifestyle identity was above 0.7 , indicating that both scales are reliable (Nunnaly 1978).

Prior to the main surveys, a pilot study (Czaja and Blair 2005) was conducted with 10 reef tourism enterprises in Airlie Beach in the Whitsundays 
Table 2. Items in the composite scale for lifestyle identity measured on a 5 point Likert scale $(1=$ strongly disagree/negative, $5=$ strongly agree/positive), Cronbach's $\alpha=0.771 ; \mathrm{n}=46$.

\begin{tabular}{lcccc}
\hline \hline Statement & Mean & SD & $\begin{array}{c}\text { Corrected Item- } \\
\text { Total Correlation }\end{array}$ & $\begin{array}{c}\text { Cronbach's } \alpha \text { if } \\
\text { item deleted }\end{array}$ \\
\hline I love working in reef-based tourism & 4.630 & 0.532 & 0.648 & 0.774 \\
$\begin{array}{l}\text { I do not think that there is a better job or work } \\
\text { environment than the reef-based tourism sector }\end{array}$ & 3.957 & 0.942 & 0.623 & 0.769 \\
$\begin{array}{l}\text { I enjoy working in an industry where I share my } \\
\text { knowledge and experiences of the reef and marine } \\
\text { environment with others }\end{array}$ & 4.44 & 0.779 & 0.546 & 0.787 \\
$\begin{array}{l}\text { I enjoy the lifestyle associated with working in the } \\
\text { reef-based tourism sector }\end{array}$ & 4.391 & 0.682 & 0.696 & 0.747 \\
$\begin{array}{l}\text { Working in the reef-based tourism sector is an } \\
\text { important part of who I am and how I see myself }\end{array}$ & 3.978 & 0.907 & 0.571 & 0.785 \\
\hline
\end{tabular}

region to evaluate the survey tool and composite scales. After refinement of survey questions, the main surveys were administered between August and November 2008. Surveys were conducted with either owners or senior managers of a total of 48 enterprises, 27 from the Cairns region and 21 from the Whitsundays region. This represented all enterprises in the two regions willing to participate in an interview, amounting to $64 \%$ and $61 \%$ of active enterprises for the Cairns and Whitsundays regions, respectively.

Scenarios of large shocks were presented during the interviews in which respondents were asked to provide an indication of how they would respond and whether they would exit the reef tourism industry in the face of a $10 \%, 30 \%$, or $50 \%$ slump in tourist revenue for a period of 12 months (based on an approach by Cinner et al. 2009). The interviewee responses for social capital, access to finance in a shock scenario, and financial condition in a shock scenario (see Table 1) used in the analyses were those given in the face of a 50\% shock scenario, when access to social and financial capital is most important for enterprise survival. However, out of the 48 enterprises surveyed, eight indicated that they would exit the reef tourism industry if faced with a $30 \%$ slump scenario. For these eight enterprises, the social and financial capital scores were taken in the face of a $30 \%$ slump. Enterprises were also asked about the most important actions that government or an external agency could take to support companies in the reef tourism sector during a disturbance. Wherever possible, information was collected from representatives of enterprises that had left the reef tourism sector, and a time line of factors that led to their withdrawal from the reef tourism industry was established. Information was gained about three companies from the Whitsundays region that had left the sector or destination.

\section{Analyses}

The composite scale of enterprise resilience, and whether or not a company would exit reef tourism in the face of a large shock scenario, were the dependent variables in separate binary logistic regression analyses. The average score of respondents on the composite scale for enterprise resilience was collapsed from five categories to two. This was necessary because some categories in the 5 point scale had very few entries. A score of 1 was given if an enterprise displayed a high level of enterprise resilience (a score of 4 or 5 on the 5 point scale) and a score of 0 if an enterprise displayed a low or average level of enterprise resilience (a score of 1,2 , or 3 ; Table 4). SPSS ${ }^{\circledR}$ version 16 was used to process regression analyses. The backward 
Table 3. Items in the composite scale for social resilience, measured on a 5 point Likert scale $(1=$ strongly disagree/negative, $5=$ strongly agree/positive), Cronbach's $\alpha=0.764 ; n=47$.

\begin{tabular}{lccc}
\hline \hline Statement & Mean & SD & $\begin{array}{c}\text { Corrected Item- } \\
\text { Total Correlation }\end{array}$ \\
$\begin{array}{l}\text { Cronbach's } \alpha \text { if } \\
\text { item deleted }\end{array}$ \\
$\begin{array}{l}\text { My business is in a better position to cope with } \\
\text { changes and stay in the reef-based tourism sector than } \\
\text { others I know }\end{array}$ & 3.872 & 0.849 & 0.565 \\
$\begin{array}{l}\text { I am confident things will turn out well for my } \\
\text { business in the future }\end{array}$ & 3.787 & 0.778 & 0.643 \\
$\begin{array}{l}\text { There are many options for my business to adapt to } \\
\text { changes and stay working in the reef-based tourism } \\
\text { sector }\end{array}$ & 3.681 & 0.934 & 0.621 \\
$\begin{array}{l}\text { I do not think that my company will survive in this } \\
\text { sector for much longer (negatively phrased) }\end{array}$ & 4.04 & 0.690 & 0.415 \\
$\begin{array}{l}\text { There is no reason to believe that foreseeable changes } \\
\text { will make my business go under }\end{array}$ & 3.670 & 0.915 & 0.660 \\
\hline
\end{tabular}

stepwise variable entry function using the likelihood ratio and the corrected Akaiki's Information Criteria (AICc; Burnham and Anderson 2002) was used. The Variance Inflation Factor for all variables was between 1.07 and 1.5, well below the 'cause for concern' level of 2.5 (Allison 1999). Stepwise removal of variables was continued until the most parsimonious model of best fit with the lowest AICc score was achieved. The regression was reanalyzed with the removal of the single very large enterprise with 500 employees (Tables 5, 6, and 7); results remained the same.

\section{RESULTS}

Enterprises surveyed had an average age of 13.2 years (Table 5), with considerable variation in enterprise size. Two enterprises had over 100 employees and $52 \%$ of enterprises had ten or less employees. Enterprises had an average of 32.7 employees and a median of 9.5. Enterprises indicated that the coral reefs that are the focus of their tourist activities were on average in good condition (average score 4.0). Human capital was considered to be good on average (average score 3.8 ), while social capital, financial condition in a shock scenario, and access to finance in a shock scenario scored lower (Table 5).

Thirty-seven $(77 \%)$ of enterprises surveyed had not experienced a shock of $25 \%$ or more reduction in tourist revenue lasting at least three months (Table 4). Thirty-five ( $83 \%$ ) of enterprises displayed a high score using the composite scale for enterprise resilience. Sixteen $(33 \%)$ of enterprises indicated that they would not exit the reef tourism industry in the face of a shock of a $50 \%$ reduction in tourism revenue for 12 months.

The binary logistic regression analysis shows that human capital $(\mathrm{p}=0.015)$ and lifestyle identity $(\mathrm{p}$ $=0.02$ ) were positively related to the composite score of enterprise resilience (Table 6). Human capital $(\mathrm{p}=0.03)$ was also positively related to whether enterprises would stay in the reef tourism sector after a shock scenario (Table 7).

Qualitative information on the three enterprises that had exited reef tourism supported the quantitative data. One enterprise exited the reef tourism sector earlier than it would have under better circumstances, but was looking to exit for personal and lifestyle reasons in any case, as reflected by this anonymous quote: "The owner wanted to exit the 
Table 4. Absolute and relative frequencies for the binary variables.

\begin{tabular}{lccccc}
\hline \hline Variable & Mean & Median & Std Dev & Min & Max \\
\hline Enterprise age in years & 13.19 & 11.50 & 9.31 & 0.75 & 35 \\
Number of employees (enterprise size) & 32.68 & 9.50 & 75.65 & $1.5^{\dagger}$ & 500 \\
Condition of coral reefs & 4.02 & 4 & 0.91 & 1 & 5 \\
Social capital & 2.53 & 2.33 & 1.26 & 1 & 5 \\
Access to finance in a systemic shock scenario & 2.33 & 2 & 1.39 & 1 & 5 \\
Financial condition in shock scenario & 1.68 & 1.44 & 0.662 & 1 & 3.33 \\
Human capital & 3.79 & 4 & 0.80 & 2 & 5 \\
\hline
\end{tabular}

$\dagger 0.5$ due to a part time employment

sector for lifestyle reasons anyway. The fact that one of his boats was destroyed in a storm, just made him do it faster."

Other companies exited reef tourism because of financial difficulties, caused by bad management or low levels of tourist demand: "The company was poorly managed, and they just did not have the cash to continue and had to sell out" and "The level of tourist demand we experienced was $70 \%$ less than expected, and we knew we had to either close down or move to another location."

\section{Government interventions and support}

The top six government interventions that reefbased enterprises felt would be valuable in a shock scenario are: financial (41\%) and marketing (26\%) support, temporarily reducing or suspending permit fees $(13 \%)$, streamlining of regulations $(9 \%)$, improving aviation access $(9 \%)$, providing training (1\%) and devaluing the Australian Dollar (1\%; Fig. 2 ). Although only $8.7 \%$ of responses indicated that streamlining regulations is a key intervention, these respondents did express their concern over regulations becoming increasingly complex and inflexible. Two anonymous quotes from reef tour operators highlight this concern: "Due to the increasing regulations, reef tourism is no longer fun and it has become more and more difficult to find good staff, many of whom choose to work in this sector for lifestyle reasons" and "Scuba diving has its risks and sometimes people die. Dive tourism has now largely moved to Thailand as in Thailand you are allowed to die when diving. In Queensland, you are not allowed to die when diving."

\section{DISCUSSION AND CONCLUSIONS}

Although the importance of applying a resilience lens to tourism systems has been highlighted and investigated qualitatively (Farrel and TwiningWard 2004, Cochrane 2010, Strickland-Munro et al. 2010, Ruiz-Ballesteros 2011), this is the only study that tries to quantify the determinants of enterprise resilience in the reef tourism sector. Elevated lifestyle identity among staff and a high level of human capital are the two strongest determinants of perceived resilience of reef tourism enterprises on the Great Barrier Reef.

The finding that lifestyle identity is positively related to enterprise resilience is consistent with research on small tourism firms elsewhere (Shaw and Williams 2004). Lifestyle choices are often a strong factor in decisions made by owners of small tourism firms, particularly in rural areas (Thomas 
Table 5. Descriptive statistics for the single item quantitative and ordinal explanatory variables all measured on a 5 point Likert scale ( $1=$ strongly disagree/negative, $5=$ strongly agree/positive) other than enterprise age.

\begin{tabular}{lccccc}
\hline \hline Variable & Mean & Median & Std Dev & Min & Max \\
\hline Enterprise age in years & 13.19 & 11.50 & 9.31 & 0.75 & 35 \\
Number of employees (enterprise size) & 32.68 & 9.50 & 75.65 & $1.5^{\dagger}$ & 500 \\
Condition of coral reefs & 4.02 & 4 & 0.91 & 1 & 5 \\
Social capital & 2.53 & 2.33 & 1.26 & 1 & 5 \\
Access to finance in a systemic shock scenario & 2.33 & 2 & 1.39 & 1 & 5 \\
Financial condition in shock scenario & 1.68 & 1.44 & 0.662 & 1 & 3.33 \\
Human capital & 3.79 & 4 & 0.80 & 2 & 5 \\
\hline
\end{tabular}

$\dagger 0.5$ due to a part time employment

et al. 1997, Ateljevic and Doorne 2000). Lifestyledriven entrepreneurs, not solely driven by profit, are willing to absorb and tolerate poor financial performance and, in some cases, accept a greater degree of risk (Hall and Rusher 2004). There is variation in the extent to which lifestyle entrepreneurs aim to make at least some profit, are content with breaking even, or are willing to tolerate moderate financial losses. Some lifestyle-driven entrepreneurs operate on the verge of bankruptcy, content with the modest revenue their enterprise provides for living a chosen lifestyle (Ateljevic 2007). Furthermore, Getz et al. (2004) suggest that owner-operators of small tourism enterprises can develop an emotional attachment to their businesses. The associated sense of place and lifestyle makes them reluctant to abandon the enterprise in difficult times. Such lifestyle-driven entrepreneurs, measured in this paper through the lifestyle identity score, are therefore likely to stay in the reef tourism sector for longer periods, and under more trying circumstances, than businesses solely driven by profit.

This study showed that human capital is a vital component of enterprise resilience. In specialist markets such as reef tourism, human capital is considered essential in providing a quality product and a memorable experience to visitors (Burns 1997, Kaplan 2004). Furthermore, a tourism enterprise whose owners and staff have the capacity to be flexible and adaptive is able to anticipate and respond to crises (Irvine and Anderson 2004). In light of the importance of human capital, it is noteworthy that additional training and skills development was considered a low priority by enterprises as a government support mechanism in a shock scenario. This result is probably because in a shock scenario, enterprise owners and managers are more concerned with immediate financial survival than building skills and capacities to strengthen their resilience in the longer term. This finding suggests that times of stability and growth in the reef tourism sector may be the best times to conduct training and skills development programs aimed at strengthening the resilience of enterprises to future shocks. A valuable contribution of future research will be to analyze how different components of human capital, such as a flexible and adaptive mind-set and attitudes toward dealing with disturbance and change, measured in different ways, affect enterprise resilience. Additionally, this research's finding that enterprise age has a positive influence on whether enterprises indicated they would stay in reef tourism in a shock scenario is commensurate with the findings of more 
Table 6. Logistic regression analysis of the explanatory variables for enterprise resilience (Corrected Akaike's Information Criterion score $=39.67$ ).

\begin{tabular}{|c|c|c|c|c|c|}
\hline Variable & $\mathrm{B}$ & S.E. & Wald & Sig. & Odds Ratio \\
\hline $\begin{array}{l}\text { Human capital measured as the confidence of owners } \\
\text { and managers in the ability of an enterprise's key } \\
\text { staff to successfully adapt to future changes }\end{array}$ & 2.200 & 0.901 & 5.964 & $0.015^{*}$ & 9.021 \\
\hline Lifestyle identity & 2.201 & 0.946 & 5.417 & $0.020^{*}$ & 9.034 \\
\hline $\begin{array}{l}\text { Average of revenue, profit, and assets to liabilities } \\
\text { ratio in systemic shock scenario }\end{array}$ & 1.696 & 1.025 & 2.736 & 0.098 & 0.379 \\
\hline Ecological state of coral reefs & -0.970 & 0.693 & 1.960 & 0.161 & 5.450 \\
\hline Constant & -14.656 & 5.579 & 6.902 & 0.009 & 0.000 \\
\hline
\end{tabular}

$*=p$ value of $<0.05$

widespread business and tourism research (Bosma et al. 2004, Cioccioa and Michael 2007).

Perceived reef condition was not a significant determinant of the resilience of reef tour operators in this study. However, most enterprises reported to have access to reefs that are in good condition (Table 4). The majority of studies elsewhere show decreased willingness to visit and decreased revenue from tourism to reefs following bleaching and degradation (Westmacott et al. 2000, Uyarra et al. 2005, 2009). However, one study showed that tourists who experience a decline in utility, i.e., enjoyment and satisfaction, after reef degradation were nonetheless still willing to visit (Andersson 2007). Clearly, more research is needed on how perceived reef quality affects tourist demand and the extent to which ecological metrics of reef condition are related to tourist perception of reef condition (Uyarra et al. 2009). The role of marketing, and how it may increase tourist demand, possibly even in the face of deteriorating ecological conditions of reefs, also requires investigation. The different market segments of reef tourism may also display differing levels of environmental awareness and responses to reef degradation. For example, specialist, experienced divers are likely to be more aware of reef condition, and more likely to specifically target destinations known for high quality reefs than first time or casual snorkelers.
Reef tourism enterprises on the GBR have to comply with overlapping regulations of numerous state and national agencies (Wilks and Davis 2000, Parker 2002). These include the Queensland Department of the Environment and the Great Barrier Reef Marine Park Authority who are responsible for the conservation of islands and the reef within the Great Barrier Reef Marine Park, respectively. Reef tourism enterprises need to abide by regulations of two state agencies, Maritime Safety Queensland and Queensland Workplace Health and Safety, and one federal agency, the Australian Maritime Safety Authority, that govern maritime and diving safety for operators and tourists. This bureaucratic complexity likely contributes to enterprise concerns over increasingly complex and inflexible regulations. Excessive regulation or overcompliance is a recognized concern of the Australian government (Regulation Taskforce 2006). In light of an increasingly competitive global market for reef tourism, effectiveness, costs, and benefits associated with regulations need to be considered with greater scrutiny.

Although the results of this study are from Australia's Great Barrier Reef, a high income part of the world, characterized by good governance and political and economic stability, the results presented are also of relevance to other regions. Human capital and lifestyle identity, the two most important variables in enabling enterprise resilience 
Table 7. Regression model for enterprises that do not exit under a 50\% systemic shock scenario (Corrected Akaike's Information Criterion score $=49.31$ ).

\begin{tabular}{lccccc}
\hline \hline Variable & B & S.E. & Wald & Sig. & Odds Ratio \\
\hline $\begin{array}{l}\text { Human capital measured as the confidence of owners } \\
\text { and managers in the ability of an enterprises' key } \\
\text { staff to successfully adapt to future changes }\end{array}$ & 1.764 & 0.784 & 5.02 & $0.03 *$ & 5.79 \\
$\begin{array}{l}\text { Enterprise age in years (natural logarithm) } \\
\text { Constant }\end{array}$ & 0.7081 & 0.413 & 2.93 & 0.09 & 2.03 \\
\hline$*$ p value of $<0.05$ & -9.575 & 3.35 & 7.73 & 0.05 & 0.00 \\
\hline
\end{tabular}

in this study, are largely internal business issues. Because reef entrepreneurs in other countries are often attracted to reef tourism for the same reasons as in Australia, human capital and lifestyle identity are likely to also play a role in fostering enterprise resilience in other countries. Policies and actions by governments, including in low income countries, which strengthen the human capital in enterprises by, for example, allowing work permits for skilled foreign staff and recognizing lifestyle benefits, are likely to strengthen the resilience of the reef tourism industry.

\section{Directions for future research}

Resilience is a complex concept and this paper represents only a starting point in our understanding of enterprise resilience in reef tourism. Studies of enterprise resilience in interactive social-ecological systems need to integrate resilience science with tourism and business research. This study has taken a first step toward that integration. A resilience lens contributes a more explicit consideration of dynamic interactions between social and ecological components of a system, and builds upon a quantitative, empirical tradition from the ecological sciences. The tourism and business literature on resilience and adaptation is largely qualitative and conceptual (e.g., Farrell and Twining-Ward 2004, Baker and Coulter 2007, Cioccioa and Michael 2007, Hall 2009, Cochrane 2010, Hjalager 2010). However, the tourism and business literature includes an extensive discussion of innovation that is pertinent to understanding the resilience of enterprises and the social-ecological systems in which they are actors.

Innovation within an enterprise can take place at different value creation points (sensu Hall 2009). Value creation points are areas of enterprise activity at which innovation is possible. Enterprises that are able to innovate and adapt across a wider range of value creation points are likely to be more resilient to crises and change (Hall and Williams 2008, Hall 2009). Literature on value creation points identifies three additional issues that require consideration in future research on enterprise resilience: first, the design, development, and distribution processes of services and products that an enterprise has to offer; second, marketing and communication of products, values, and expectations associated with an enterprise's brand; and third, the management of customer satisfaction, loyalty, and experience (Hall 2009). An understanding and measure of an enterprise's ability to innovate across a wider range of activities will provide a more nuanced understanding of enterprise resilience.

Internal processes within enterprises can enable or hinder innovation and adaptation (Hoffman et al. 2009, Hjalager 2010). Constraints to innovation such as barriers to learning can make enterprises more vulnerable to external crises as well as selfinduced crises. An important issue for future research is how management systems within an enterprise can create or prevent their own crises (Smith 2005, de Sausmarez 2007). An enterprise 
Fig. 2. Frequencies of suggested government interventions in a crisis scenario by reef tourism enterprises (41 enterprises, 69 intervention suggestions).

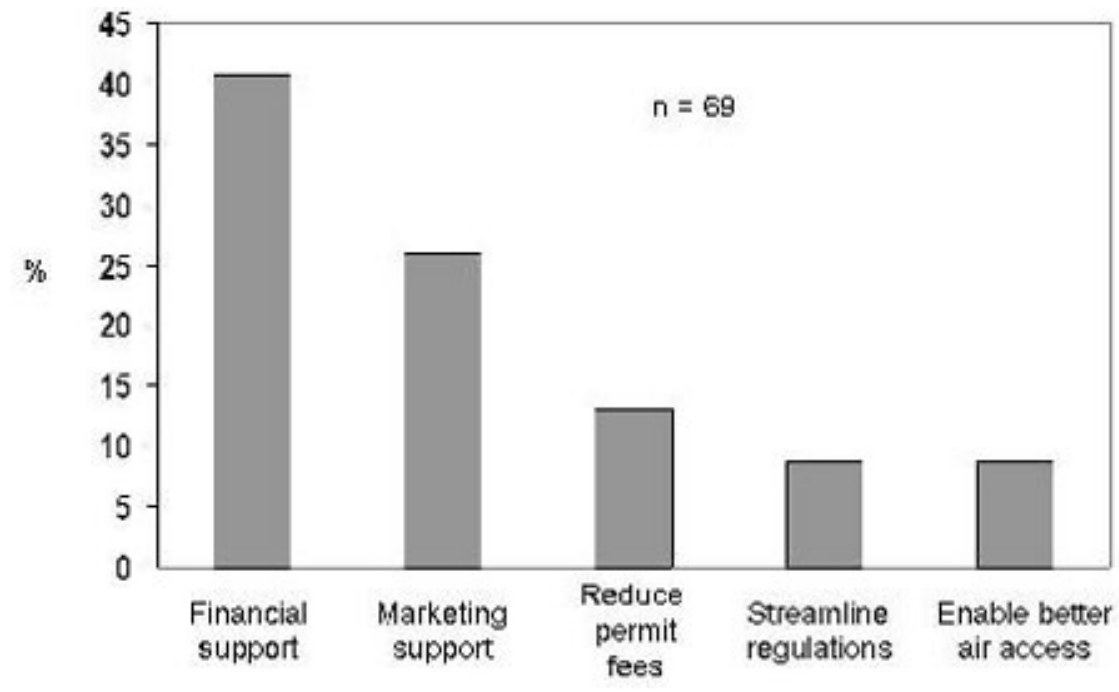

that is open to learning is more resilient and able to adapt in the face of an external crisis (de Sausmarez 2007).

Tourism enterprises are also embedded within destination and national systems that may or may not support and enable innovation (Hall 2009). Although this study has pointed to areas where government can play a stronger role in enabling enterprise resilience, future research could focus in more detail on how stronger regional and national innovation systems can be fostered. Such systems would entail a greater potential and support for innovation within and between enterprises, within civil society and government, and between civil society, government, and enterprises (Hall 2009, Hjalager 2010).

Integration of business research into resilience science can also advance understanding of the relationship between enterprise resilience and the broader social-ecological systems of which enterprises are one part. An example of a research question that can be addressed by integrating business and resilience research is to quantify the relationship between enterprise resilience and enterprise contribution to maintaining the health of a natural resource, e.g., coral reefs, on which they depend. An understanding of this relationship will shed light on the role of enterprises in enhancing the resilience of ecological systems.

Finally, enterprise resilience is a way in which actors in vulnerable economic sectors like reef tourism can be conceptualized and understood. An understanding of enterprise resilience will aid enterprises and policy makers to navigate a future of escalating global change and the associated crises and disturbances. This exploratory study represents a starting point for further research on the resilience of reef tourism and other similarly vulnerable economic sectors. In particular, future studies on the resilience of reef tourism in the aftermath of a large disturbance, and a comparison with the findings of this study, would be valuable. Finally, this paper provides a basis for policy makers in Australia and elsewhere to start actively considering lifestyle identity and human capital in establishing policies and regulations to enhance the resilience of the iconic reef tourism sector.

Responses to this article can be read online at: http://www.ecologyandsociety.org/voll6/iss 1/art30/ responses/ 


\section{Acknowledgments:}

The ARC Centre of Excellence for Coral Reef Studies provided the funding for this research. I sincerely thank all the reef tourism enterprises and their staff who gave up their valuable time to participate in this research. I am grateful to two anonymous reviewers, Terry Hughes, Joshua Cinner, Lance Gunderson, Natalie Stoeckl, Natalie Ban, Nadine Marshall, Michael Hall, and Erin Bohensky for their valuable comments and insights and for reviewing earlier versions of this manuscript.

\section{LITERATURE CITED}

Access Economics. 2007. Measuring the economic \& financial value of the Great Barrier Reef Marine Park, 2005-6. Great Barrier Reef Marine Park Authority, Townsville, Queensland, Australia. [online] URL: http://www.gbrmpa.gov.au/corp site/ info services/publications/research publications/rp088/ access economics report 0607.

Adger, W. N. 2000. Social and ecological resilience: are they related? Progress in Human Geography 24:347-364.

Adger, W. N. 2003. Social capital, collective action, and adaptation to climate change. Economic Geography 79:387-404.

Adger, W. N., H. Eakin, and A. Winkels. 2009. Nested and teleconnected vulnerabilities to environmental change. Frontiers in Ecology and the Environment 7:150-157.

Allison, P. D. 1999. Logistic regression using the SAS system - theory and application. SAS Institute, Cary, North Carolina, USA.

Andersson, J. E. C. 2007. The recreational cost of coral bleaching - a stated and revealed preference study of international tourists. Ecological Economics 62:704-715.

Ateljevic, J. 2007. Small tourism firms and management practices in New Zealand: the centre stage macro region. Tourism Management 28:307-316.

Ateljevic, I., and S. Doorne. 2000. Staying within the fence': lifestyle entrepreneurship in tourism. Journal of Sustainable Tourism 8:378-392.

Baker, K., and A. Coulter. 2007. Terrorism and tourism: the vulnerability of beach vendors' livelihoods in Bali. Journal of Sustainable Tourism 15:249-265.

Balmford, A., J. Beresford, J. Green, R. Naidoo, M. Walpole, and A. Manica. 2009. A global perspective on trends in nature-based tourism. Plos Biology 7. [online] URL: http://www.ncbi.nlm.nih.gov/pmc/a rticles/PMC2694281/.

Bates, T. 1990. Entrepreneur human capital inputs and small business longevity. Review of Economics and Statistics 72:551-559.

Beattie, A. 2008. Rush to restrict trade in basic foods. Financial Times. In Depth: The Global Food Price Crisis. 1 April.

Bellwood, D. R., T. P. Hughes, C. Folke, and M. Nystrom. 2004. Confronting the coral reef crisis. Nature 429:827-832.

Berkhout, F., J. Hertin, and D. M. Gann. 2006. Learning to adapt: organisational adaptation to climate change impacts. Climatic Change 78:135-156.

Bernard, H. R. 2002. Research methods in anthropology. Qualitative and quantitative approaches. Third Edition. Altamira Press, Lanham, Maryland, USA.

Bosma, N., M. van Praag, R. Thurik, and G. de Wit. 2004. The value of human and social capital investments for the business performance of startups. Small Business Economics 23:227-236.

Brunnermeier, M. 2009. Deciphering the liquidity and credit crunch of 2007-2008. Journal of Economic Perspectives 23:77-100.

Burnham, B. P., and D. R. Anderson 2002. Model selection and multimodel inference. Springer, New York, New York, USA. 
Burns, P. M. 1997. Hard-skills, soft-skills: undervaluing hospitality's service with a smile. Progress in Tourism and Hospitality Research 3:239-248.

Carpenter, S., F. Westley, and M. Turner. 2005. Surrogates for resilience of social-ecological systems. Ecosystems 8:941-944.

Cesar, H. 2000. Coral reefs: their functions, threats and economic value. Pages 14-39 in H. Cesar, editor. Collected essays on the economics of coral reefs. CORDIO, Kalmar University, Sweden.

Cinner, J. E., T. Daw, and T. R. McClanahan. 2009. Socioeconomic factors that affect artisanal fishers' readiness to exit a declining fishery. Conservation Biology 23:124-130.

Cioccioa, L., and E. J. Michael. 2007. Hazard or disaster: tourism management for the inevitable in Northeast Victoria. Tourism Management 28:1-11.

Cochrane, J. 2010. The sphere of tourism resilience. Tourism Recreation Research 35:173-186.

Cumming, G. S., G. Barnes, S. Perz, M. Schmink, K. Sieving, J. Southworth, M. Binford, R. D. Holt, C. Stickler, and T. Van Holt. 2005. An exploratory framework for the empirical measurement of resilience. Ecosystems 8:975-987

Czaja, R., and J. Blair 2005. Designing surveys: a guide to decisions and procedures. Sage, Thousand Oaks, California, USA.

Deng, J., B. King, and B. Bauer. 2002. Evaluating natural attractions for tourism. Annals of Tourism Research 2:422-438.

de Sausmarez, N. 2007. Crisis management, tourism and sustainability: the role of indicators. Journal of Sustainable Tourism 15:700-714

Dunne, P., and A. Hughes. 1994. Age, size, growth and survival: UK companies in the 1980s. Journal of Industrial Economics 42:115-140.

Farrell, B. H., and L. Twining-Ward. 2004. Reconceptualising tourism. Annals of Tourism Research 31:274-295.
Folke, C., T. Hahn, P. Olsson, and J. Norberg. 2005. Adaptive governance of social-ecological systems. Annual Review of Environment and Resources 30:441-473.

Fritsch, M., U. Brixy, and O. Falck. 2006. The effect of industry, region, and time on new business survival - a multidimensional analysis. Review of Industrial Organisation 28:285-306.

Getz, D., J. Carlsen, and A. Morrison. 2004. The family business in tourism and hospitality. CABI, Oxfordshire, UK.

Gössling, S., editor. 2003. Tourism and development in tropical islands: political ecology perspectives. Eldward Elgar, Northampton, Massachusetts, USA.

Gössling, S., and C. Hall. 2006. Uncertainties in predicting tourist flows under scenarios of climate change. Climatic Change 79:163-173.

Graham, T., N. Idechong, and K. Sherwood. 2001. The value of dive tourism and the impacts of coral bleaching on diving in Palau. Pages 59-71 in H. Z. Schuttenberg, editor. Coral bleaching: causes, consequences and response. Selected papers presented at the 9th International Coral Reef Symposium on Coral Bleaching: Assessing and Linking Ecological and Socioeconomic Impacts, Future Trends and Mitigation Planning. Coastal Management Report \#2230. Costal Resources Center, University of Rhode Island, Narragansett, Rhode Island, USA.

Great Barrier Reef Marine Park Authority (GBRMPA). 2009. Great Barrier Reef tourist numbers. Great Barrier Reef Marine Park Authority, Townsville, Queensland, Australia. [online] URL: http://www.gbrmpa.gov.au/corp site/key issues/tourism/ management/gbr visitation/numbers.

Gunderson, L., and C. Holling, editors. 2002. Panarchy: understanding transformations in human and natural systems. Island Press, Washington, D.C., USA

Hall, C. M. 2009. Tourism firm innovation and sustainability. Pages 282-298 in S. Gössling, C. M. Hall, and D. B. Weaver, editors. Sustainable tourism futures: perspectives on systems, restructuring and 
innovations. Routledge, New York, New York, USA.

Hall, C. M. 2010. Crisis events in tourism: subjects of crisis in tourism. Current Issues in Tourism 13:401-417.

Hall, C. M., and K. Rusher. 2004. Risky lifestyles: entrepreneurial characteristics of the New Zealand bed and breakfast sector. Pages 83-99 in R. Thomas, editor. Small firms in tourism: international perspectives. Eslevier, Oxford, UK.

Hall, C. M., D. J. Timothy, and D. T. Duval. 2003. Security and tourism - towards a new understanding? Journal of Travel \& Tourism Marketing 15:1-18.

Hall, C. M., and A. Williams. 2008. Tourism and innovation. Routledge, London, UK.

Hennessy, K., B. Fitzharris, B. C. Bates, N. Harvey, S. M. Howden, L. Hughes, J. Salinger, and R. Warrick. 2007. Australia and New Zealand. Chapter 11 in M. L. Parry, O. F. Canziana, J. P. Palitikof, P. $\mathrm{J}$. van der Linder, and C. E. Hanson, editors. Climate change 2007: impacts, adaptation and vulnerability. Contribution of Working Group II to the Fourth Assessment Report of the Intergovernmental Panel on Climate Change. Cambridge University Press, Cambridge, UK.

Hjalager, A. M. 2010. A review of innovation research in tourism. Tourism Management 31:1-12.

Hoffmann, V. H., D. C. Sprengel, A. Ziegler, M. Kolb, and B. Abegg. 2009. Determinants of corporate adaptation to climate change in winter tourism: an econometric analysis. Global Environmental Change 19:256-264.

Holtz-Eakin, D., D. Joulfaian, and H. S. Rosen. 1994. Sticking it out: entrepreneurial survival and liquidity constraints. Journal of Political Economy 102:53-75.

Hughes, T. P., A. H. Baird, D. R. Bellwood, M. Card, S. R. Connolly, C. Folke, R. Grosberg, O. Hoegh-Guldberg, J. B. C. Jackson, J. Kleypas, J. M. Lough, P. Marshall, M. Nystrom, S. R. Palumbi, J. M. Pandolfi, B. Rosen, and J. Roughgarden. 2003. Climate change, human impacts, and the resilience of coral reefs. Science 301:929-933.
Intergovernmental Panel on Climate Change (IPCC). 2007. Climate change 2007: synthesis report. Contribution of Working Groups I, II and III to the Fourth Assessment Report of the Intergovernmental Panel on Climate Change. Report of the Intergovernmental Panel on Climate Change (IPCC), Geneva, Switzerland.

Irvine, W., and A. R. Anderson. 2004. Small tourist firms in rural areas: agility, vulnerability and survival in the face of crisis. International Journal of Entrepreneurial Behaviour \& Research 10:229-246.

Johnson, J. E., and P. A. Marshall 2007. Climate change and the Great Barrier Reef: a vulnerability assessment. Great Barrier Reef Marine Park Authority, Townsville, Queensland, Australia.

Kalleberg, A. L., and K. T. Leicht. 1991. Gender and organizational performance: determinants of small business survival and success. Academy of Management Journal 34:136-161.

Kaplan, L. 2004. Skills development in tourism: South Africa's tourism-led development strategy. GeoJournal 60:217-227.

Kragt, M. E., P. C. Roebeling, and A. Ruijs. 2009. Effects of Great Barrier Reef degradation on recreational reef-trip demand: a contingent behaviour approach. Australian Journal of Agricultural and Resource Economics 53:213-229.

Likert, R. 1967. The method of constructing an attitude scale. Pages 90-95 in M. Fishbein, editor. Readings in attitude theory and measurement. John Wiley \& Sons, New York, New York, USA.

Marshall, N. A. 2010. Understanding social resilience to climate variability in primary enterprises and industries. Global Environmental Change 20:36-43

Millennium Ecosystem Assessment. 2005. Ecosystems and human well-being: synthesis. Island Press, Washington, D.C., USA.

Moscardo, G., R. Saltzer, A. Galletly, A. Burke, and A. Hildebrandt. 2003. Changing patterns of reef tourism. CRC Reef Research Centre, Townsville, Queensland, Australia. 
Nunnaly, J. C. 1978. Psychometric theory. McGraw Hill, New York, New York, USA.

Parker, S. 2002. Management of marine tourism on Australia's Great Barrier Reef: public and private dimensions of regulation. National Sea Grant Library, Narragansett, Rhode Island, USA. [online] URL: http://nsgl.gso.uri.edu/washu/washuw99003/4Parker.pdf.

Pretty, J. 2003. Social capital and the collective management of resources. Science 302:1912-1914.

Prideaux, B. 2000. The role of the transport system in destination development. Tourism Management 21:53-63.

Regulation Taskforce. 2006. Rethinking regulation: report of the taskforce on reducing regulatory burdens on business. Report to the Prime Minister and the Treasurer, Canberra, Australia.

Rockstrom, J., W. Steffen, K. Noone, A. Persson, F. S. Chapin, E. F. Lambin, T. M. Lenton, M. Scheffer, C. Folke, H. J. Schellnhuber, B. Nykvist, C. A. de Wit, T. Hughes, S. van der Leeuw, H. Rodhe, S. Sorlin, P. K. Snyder, R. Costanza, U. Svedin, M. Falkenmark, L. Karlberg, R. W. Corell, V. J. Fabry, J. Hansen, B. Walker, D. Liverman, K. Richardson, P. Crutzen, and J. A. Foley. 2009. A safe operating space for humanity. Nature 461:472-475.

Ruiz-Ballesteros, E. 2011. Social-ecological resilience and community-based tourism: an approach from Agua Blanca, Ecuador. Tourism Management 32(3):655-666. doi:10.1016/j. tourman.2010.05.021

Seven Natural Wonders. 2008. Seven natural wonders of the world: Great Barrier Reef. Seven Natural Wonders, Irving, Texas, USA. [online] URL: http://sevennaturalwonders.org/the-original/greatbarrier-reef.

Shaw, G., and A. M. Williams. 2004. From lifestyle production to lifestyle consumption: changing patterns of tourism entrepreneurship. Pages 99-114 in R. Thomas, editor. Small firms in tourism: international perspectives. Eslevier, Oxford, UK.

Sheldon, P., and L. Dwyer. 2010. The global financial crisis and tourism: perspectives of the academy. Journal of Travel Research 49:3-4
Simpson, M. C., S. Gössling, D. Scott, C. M. Hall, and E. Gladin. 2008. Climate change adaptation and mitigation in the tourism sector: frameworks, tools and practices. UN Environment Programme, University of Oxford, UN World Tourism Organization, World Meteorological Organization, Paris, France.

Smith, D. 2005. Business (not) as usual: crisis management, service recovery and the vulnerability of organizations. Journal of Services Marketing 19:309-320.

Strickland-Munro, J. K., H. E. Allison, and S. A. Moore. 2010. Using resilience concepts to investigate the impacts of protected area tourism on communities. Annals of Tourism Research 37:499-519.

Thomas, R., M. Friel, S. Jameson, and D. Parsons. 1997. The national survey of small tourism and hospitality firms 1996-1997. Centre for the Study of Small Tourism and Hospitality Firms, Leeds Metropolitan University, Leeds, UK.

Thomson, A. 2010. US tourism suffers as BP spill keeps visitors away. Financial Times. In Depth: The BP Oil Spill. 26 August.

Tourism Queensland. 2009a. Tropical North Queensland Regional Snapshot - Year ended June 2009. [online] URL: http://www.tq.com.au/ Accessed 7 December 2009. No longer available online.

Tourism Queensland. 2009b. Whitsundays Regional Snapshot - Year ended June 2009. [online] URL: http://www.tq.com.au/ Accessed 7 December 2009. No longer available online.

United Nations World Tourism Organization (UNWTO). 2010. Recovery confirmed but growth remains uneven. World Tourism Barometer 8 (2):1-4. [online] URL: http://www.unwto.org/facts/ eng/pdf/barometer/UNWTO Barom10 2 en excerpt. pdf.

Uphoff, N., and C. M. Wijayaratna. 2000. Demonstrated benefits from social capital: the productivity of farmer organizations in Gal Oya, Sri Lanka. World Development 28:1875-1890.

Uyarra, M. C., I. M. Côté, J. A. Gill, R. R. T. Tinch, D. Viner, and A. R. Watkinson. 2005. Islandspecific preferences of tourists for environmental 
features: implications of climate change for tourism-dependent states. Environmental Conservation 32:11-19.

Uyarra, M. C., A. R. Watkinson, and I. M. Côté. 2009. Managing dive tourism for the sustainable use of coral reefs: validating diver perceptions of attractive site features. Environmental Management 43:1-16.

Westmacott, S., H. Cesar, L. Pet-Soede, and O. Linden. 2000. Coral bleaching in the Indian Ocean: socioeconomic assessment of effects. Pages 94-106 in H. Cesar, editor. Collected essays on the economics of coral reefs. CORDIO, Kalmar University, Sweden.

Wilks, J., and R. J. Davis. 2000. Risk management for scuba diving operators on Australia's Great Barrier Reef. Tourism Management 21:591-599.

Williams, A. M., G. Shaw, and J. Greenwood. 1989. From tourist to tourism entrepreneur, from consumption to production: evidence from Cornwall, England. Environment and Planning A 21:1639-1653.

Zeller, R. A., and E. G. Carmines. 1980. Measurement in the social sciences: the link between theory and data. Cambridge University Press, Cambridge, UK. 